\title{
Biomarkers and Cellular Infiltration of the Bladder in Interstitial Cystitis/Bladder Pain Syndrome
}

\author{
Interstisyel Sistit/Mesane Ağrısı Sendromunda Mesane Biyobelirteçleri ve Hücresel \\ Infiltrasyonu
}

\author{
(D) Rashad Farkhad ogly Sholan \\ Republican Centre of Diagnosis and Treatment, Head of Department of Kidney Diseases and Transplantology, Baku, Azerbaijan
}

\section{What's known on the subject? and What does the study add?}

The search for a biomarker for interstitial cystitis/painful bladder syndrome (IC/BPS) is of great interest. Assume the participation of nerve growth factor (NGF), cytokines, activated mast cells in the pathogenesis of IC/BPS. An analysis of the current literature showed a lack of consensus on the potential biomarkers of this disease. We have identified elevated levels of NGF and interleukin-8 in the urine, as well as lymphocytes and mast cells in the biopsy specimens of the bladder. However, no strong relationship between these indicators was observed.

\section{Abstract}

Objective: To study the content of nerve growth factor (NGF), interleukin (IL)-8 in the urine, mast cells, and white blood cells in a biopsy of the bladder and the relationship between them in women with interstitial cystitis/bladder syndrome (IC/BPS).

Materials and Methods: Forty-one women with IC/BPS (mean age: $46.6 \pm 14.0$ years) and 20 women without IC/BPS (mean age: $35.3 \pm 9.7$ years) were examined in this study. Cystoscopy with hydrodistension was performed. NGF and IL-8 were determined in the urine by enzyme-linked immunosorbent assay. The number of mast cells and leukocytes was determined in biopsy specimens of the bladder wall. Statistical calculations were performed in Excel 2016 (SPSS 15.0). Results were processed using the Pearson's correlation coefficient to describe the relationships between variables.

Results: Diffuse submucosal hemorrhages (43.9\%) were more common. The level of NGF was $142.26 \pm 134.906 \mathrm{ng} / \mathrm{mL}$, IL-8 was $51.3 \pm 9.36 \mathrm{pg} / \mathrm{mL}$, and lymphocytes $(238.0 \pm 166.42)$ and mast cells $(82.27 \pm 38.76)$ predominated in the biopsy specimens. A correlation of the mast cells with the plasma cells $(r=-0.228)$, neutrophils $(r=-0.227)$, and lymphocytes $(r=-0.156)$ was observed. NGF and IL-8 correlated with mast cells, neutrophils, and plasma cells with weak multidirectional bonds.

Conclusion: With IC/BPS, the concentration of NGF and IL-8 in the urine is increased. In biopsy specimens, mainly lymphocytes and mast cells, the correlation of NGF and IL-8 with mast cells, neutrophils, and plasma cells is weak. These indicators can be included in a complex of diagnostic studies.

Keywords: İnterstitial cystitis/bladder pain syndrome, Urine, Women, Nerve growth factor, Interleukin, Must Cells

\section{Öz}

Amaç: Bu araştırmanın amacı, idrar kesesi duvarı biyopsi örneklerinde idrardaki sinir büyüme faktörü (NGF), interlökin (IL) -8 seviyesini, mast hücrelerini ve beyaz kan hücrelerini araştırmak ve interstisyel sistit/mesane ağrısı sendromu (IS/MAS) kadınlarda bu parametreler arasındaki ilişkiyi değerlendirmektir.

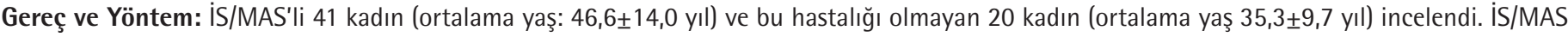
tanısı hidrodistrasyon sonrası sistoskopik verilere dayanılarak konuldu. Mesane duvarının biyopsi örneklerinde mast hücresi ve lökosit sayısı belirlendi. İstatistiksel hesaplamalar Excel 2016'da yapıldı (SPSS 15.0). Sonuçlar, değişkenler arasındaki ilişkileri tanımlamak için Pearson'un korelasyon katsayısı kullanılarak işlenmiştir.

Correspondence: Rashad Farkhad ogly Sholan MD, Republican Centre of Diagnosis and Treatment, Head of Department of Kidney Diseases and Transplantology, Baku, Azerbaijan E-mail: ittihaf@yahoo.com ORCID-ID: orcid.org/0000-0002-1047-167X

Received: 23.02.2020 Accepted: 29.05.2020

Cite this article as: Sholan RF. Biomarkers and Cellular Infiltration of the Bladder in Interstitial Cystitis/Bladder Pain Syndrome. J Urol Surg 2020; 7(3): 232-

237.

๑Copyright 2020 by the Association of Urological Surgery / Journal of Urological Surgery published by Galenos Publishing House. 
Bulgular: Hastalığın süresi $6,0 \pm 2,8$ yıl idi. Visual analog skala ve ICSI skalalarının ortalama skoru sırasıyla $5,47 \pm 0,91$ ve $14,7 \pm 2,2$ puan idi. Çoğu zaman $(\% 43,9)$ mesane duvarında submukozal kanamalar meydana geldi. İdrardaki ortalama NGF seviyesi $142,26 \pm 134,906 \mathrm{ng} / \mathrm{mL}$ ve IL-8 $-51,3 \pm 9,36$ $\mathrm{pg} / \mathrm{mL}$ idi. Biyopsi örneklerinde lenfositler $(238,0 \pm 166,42)$ ve mast hücreleri $(82,27 \pm 38,76)$ baskındır. Mast hücrelerinin sayısı, plazma hücrelerinin $(r=-0,228)$, nötrofillerin $(r=-0,227)$ ve lenfositlerin $(r=-0,156)$ zayıf geri bildirimi ile korele idi. NGF ve IL-8 seviyeleri, zayıf çok yönlü ilişkileri olan mast hücreleri, nötrofiller ve plazma hücreleri ile korelasyon gösterdi.

Sonuç: iS/MAS'li hastalarda idrardaki NGF ve IL-8 konsantrasyonu artar. Mesane biyopsi örnekleri ağırlıklı olarak lenfositler ve mast hücreleri tarafından enfiltre edilir. NGF ve IL-8 seviyeleri, zayıf ilişkileri olan mast hücrelerinin, nötrofillerin ve plazma hücrelerinin sayısı ile ilişkilidir. Elde edilen sonuçlar iS/MAS etiyolojisinin daha iyi anlaşılmasını sağlar ve teşhis prosedürleri kompleksine dahil edilebilir.

Anahtar Kelimeler: Interstisyel sistit/mesane ağrısı sendromu, İdrar, Kadınlar, Sinir büyüme faktörü, İnterlökin, Zorunlu hücreler

\section{Introduction}

Interstitial cystitis/bladder pain syndrome (IC/BPS) is one of the urological impairments that has a huge impact on one's quality of life $(1,2)$. According to the literature, 300 of every 100,000 women suffer from this disease worldwide (3).

The diagnostic criteria for this disease are complex and ambiguous. The diversity of symptoms and differences in patients' susceptibility to treatment indicate that IC/BPS has a polyetiological nature (4).

Moreover, the nature of IC/BPS is yet not fully understood. At present, there are different theories of this disease. The etiological factors of the disease include autoimmune, allergic, infectious, neurological, and vascular diseases, as well as infiltration of the bladder wall by increased number of mast cells, injury of the protective layer of the mucous membrane, and the impact on the bladder wall of toxic substances contained in urine. One of the existing theories of the disease is the activation of mast cells and neurogenic inflammation theory $(5,6)$. The lack of standard diagnostic procedure and poor correlation of the patient's clinical features with cystoscopic data or a hydrodistension procedure are some of the reasons why biomarkers are more promising for clinical diagnosis as well as for understanding the pathophysiology of IC/BPS (7). Nerve growth factor (NGF) as a potential biomarker is particularly of great interest for the diagnosis of patients with IC/PBS. Studies have shown a direct relationship between the painful inflammatory processes in the lower urinary tract and increased NGF level in bladder tissues and urine (8-10). Data from several studies have indicated the central role of activated mast cells in the IC/BPS pathogenesis and pathophysiology. When activated, mast cells secrete biologically active mediators that can cause symptoms of this disease (11). Recently in the medical scientific literature, much attention has been paid to the study of cytokines in IC/BPS. According to these studies, the interaction of cytokines and receptors can activate signaling pathways that cause transcription and release of other proinflammatory/nociceptive mediators, including NGF and other cytokines and chemokines from peripheral neurons or glial cells. The expression of cytokines alone or in combination with other cytokines, growth factors, or other mediators can form a bidirectional communication network between the nervous system and the immune system (12).

Thus, the diagnosis and management of patients is often difficult due to the incomplete clear pathogenesis of IC/BPS and its unknown etiology. IC/BPS mandates an in-depth study, basic and clinical research, especially regarding the diagnostics and biomarkers. Therefore, the etiology, pathogenesis, and clinical features of IC/BPS require in-depth fundamental and clinical investigations, especially with regard to the diagnosis of the disease and determination of the diagnostic value of biomarkers.

The aim of this research was to investigate the levels of NGF and interleukin (IL)-8 in urine, mast cells, and white blood cells in urinary bladder wall biopsy specimens and to assess the relationship between these parameters in women with IC/BPS.

\section{Materials and Methods}

This study was conducted in accordance with the principles of the World Medical Association Declaration of Helsinki: Recommendations guiding physicians in biomedical research involving human subjects (13). In addition, informed consent was obtained for each patient and the examined control group.

In this study, 41 women with IC/BPS (main group) and 20 women without IC/BPS (control group) were included. IC/ BPS was diagnosed according to the cystoscopic data after hydrodistension.

The inclusion criteria of the study were:

- Women aged 17 years and over who have had an onset of IC/ BPS signs during at least the last six months;

- Non-ulcer type of IC/BPS; and

- An absence of diabetes, arthritis, systemic lupus erythematosus.

The exclusion criteria, on the other hand, were:

- The presence of acute or exacerbation of a chronic urinary tract infection, as well as asymptomatic bacteriuria during the last three months before inclusion into the study;

- The presence of diseases or conditions that could be the cause of pelvic pain and urinary discomfort, including neurological 
diseases, bladder and ureteral stones, severe prolapse of the pelvic organs, infravesical obstruction;

- Tumors of the pelvic organs at the time of the investigation period or in anamnesis;

- Therapeutic treatment of IC/BPS for three months prior to the start of study;

- Bladder hydrodistension and/or intravesical injections of botulinum toxin in anamnesis; and

- A negative lidocaine test.

In addition, in the control group, none of the examined women had a history of IC/BPS and any diseases of the lower urinary tract.

The bladder pain in patients with IC/BPS was measured using a visual analog scale. According to this scale, each centimeter on the line corresponds to 1 point. So, the minimum value 0 represented a complete absence of pain syndrome; up to 2 points was classified as weak; 2-4 as moderate; 4-6 as strong; $6-8$ as the strongest; and the maximum value, that is, 10 corresponded to an intolerable pain.

Further, the 0'Leary-Sant Interstitial Cystitis Symptoms index (ICSI) was used to evaluate the treatment of patients with IC/ BPS (14). The scale consists of four questions, each of which is rated between 0 and 5 points, the maximum number of points being 20. The questions reflect the severity of the major IC/ BPS symptoms over the last month prior to the survey. How often have you felt the strong need to urinate with little or no warning? Have you had to urinate again less than 2 hours after you finished urinating? How often do you most typically get up at night to urinate? Have you experienced pain or burning in your bladder?

All patients underwent a comprehensive examination, including cystoscopy and hydrodistension of the bladder, which was performed in an endoscopic operating room under general anesthesia using Olympus endoscopes (Japan) with 30- and 70-degrees optics. For the analysis of cystoscopic changes, a grading system was used that included five classes: 0 - no changes in the mucosa, I- rare glomerulations at least in two quadrants, II- diffuse submucosal hemorrhages, III- diffuse mucosal bleeding, and IV- Hunner's lesions.

To determine the NGF and IL-8 in urine, $10 \mathrm{ml}$ urine was collected in a sterile test tube and the obtained biosamples were placed on ice and delivered to the laboratory within 15-20 minutes. The samples were centrifuged for $10 \mathrm{~min}$ at $3000 \mathrm{rpm}$ and a temperature of $4^{\circ} \mathrm{C}$. For storage, supernatants were poured into $1 \mathrm{~mL}$ Eppendorf tubes and stored until analysis at a temperature of $-80^{\circ} \mathrm{C}$. While the NGF was determined by the enzyme-linked immunosorbent assay using a set of NGF Emax ${ }^{\circledR}$ Medispec 6000
$\mathrm{M}$ apparatus (Israel), the concentration of IL-8 was determined by the method of solid-phase immunoenzymatic analysis using the reagent sets of Vector-Best company (Russia). Additionally, the number of mast cells and leukocytes was determined in biopsy specimens of the bladder wall taken during cystoscopy. Finally, a deep biopsy from the bladder wall till the muscle layer was performed under short-term intravenous anesthesia. The biopsy site was re-examined after which the cystoscope was removed, and 30-60 minutes later the patients urinated on their own. Moreover, after a biopsy of the bladder wall, the patients were monitored for 5-6 hours. No cases of bleeding or other complications were noted. Samples of biopsies were fixed in 10\% buffer of a neutral solution of formalin. Next, the specimens were prepared in alcohol solutions at the concentrations of 75\%,85\%, 95\%, and 99.9\%. Subsequently, the samples were contained in a xylene solution and enclosed in paraffin blocks from which serial sections 3-5 microns were prepared and stained by the May-Grünwald-Giemsa method to detect mast cells. Each cross-section was divided into 10 areas. Cell infiltration was evaluated in each of these areas using the following scale: $0-$ no cells; $1-<20$ cells; $2-20-45$ cells; $3->45$ cells. The points of all 10 sections were added and then divided by 30 (maximum possible score) and multiplied by 100 . Therefore, the cell scores were the average of the three studied sections. Microscopy was performed at $\times 200$ magnification (15).

\section{Statistical Analysis}

Data were analyzed using Excel 2016 (SPSS 15.0). Statistical indicators were expressed as mean \pm standard deviation as well as in numbers and percentages. The Pearson's correlation coefficient was calculated to describe the relationships between variables, and $p<0.05$ was considered as statistically significant.

\section{Results}

The patients in this study were aged between 21 and 76 years, with a mean age of $46.6 \pm 14.0$ years. Out of the 41 women with IC/BPS, 12 patients (29.3\%) were of reproductive age and 29 (70.7\%) of premenopausal and menopausal age. In the control group, the age of the examined women ranged between 17 and 53 years and the average age was $35.3 \pm 9.7$ years.

In the main group, based on the obstetric-gynecologic history, $2(4.9 \%)$ women had no pregnancies and the 39 (95.1\%) had one-four pregnancies; 4 (10.3\%) women belonged to the unborn and 35 (89.7\%) had 1-3 genera; and $4(10.3 \%)$ women were nulliparous and 35 (89.7\%) had 1-3 births. Overall, gynecological diseases were registered in 12 (29.3\%) women, and there were $9(22.0 \%)$ cases of pelvic organ prolapse and $3(7.3 \%)$ cases of uterine myoma. While more than half of the observed patients 
(58.5\%) could not associate the onset of IC/BPS symptoms with any history event, 11 (26.8\%) associated them with previous urinary tract infections and $6(14.6 \%)$ indicated emotional stress as a possible reason for the development of IC/BPS. Table 1 presents the clinical characteristics of the examined main group.

Of note, in the control group, there were equal number of women at reproductive age and those at premenopausal and menopausal age, that is, $10(50 \%)$ in each age group.

When comparing the main and control groups, a statistically smaller number of women with IC/BPS of reproductive age $(41.4 \%, p<0.05)$ and a larger number of premenopausal and menopausal women $(29.28 \%, p<0.05)$ were revealed. During the cystoscopy in women in the control group, no changes in the mucous membrane of the bladder were detected.

According to the results of the ICSI scale, the largest number of patients, that is, $23(56.1 \%)$ had 14 points, $2(4.9 \%)$ had a minimum score of 10, and $6(14.6 \%)$ had a maximum score of 20 . In 24 (58.5\%) patients, urination more than 8 times a day was noted.

While the level of NGF in urine in the main group ranged from 35.7 to $848.8 \mathrm{ng} / \mathrm{mL}$, which averaged $142.26 \pm 134.906 \mathrm{ng} / \mathrm{mL}$, in

\begin{tabular}{|c|c|c|}
\hline \multicolumn{3}{|c|}{$\begin{array}{l}\text { Table } 1 \text {. Clinical characteristics of patients with interstitial } \\
\text { cystitis/bladder pain syndrome }\end{array}$} \\
\hline Indicators & $\begin{array}{l}\text { Main group } \\
(n=41)\end{array}$ & $\begin{array}{l}\text { Control } \\
\text { group } \\
(n=20)\end{array}$ \\
\hline Age $21-44$ years, $n / \%$ & $12 / 29.3$ & $10 / 50.0$ \\
\hline Age $45-76$ years, $n / \%$ & $29 / 70.7$ & $10 / 50.0$ \\
\hline Duration of the disease, years & $6.0 \pm 2.8$ & - \\
\hline The average score of the VAS & $5.47 \pm 0.91$ & - \\
\hline 2-4 points (mild pain), n/\% & $8 / 19.5$ & - \\
\hline 5-6 points (moderate pain), $n / \%$ & $23 / 56.1$ & - \\
\hline 7-8 points (severe pain), $\mathrm{n} / \%$ & $10 / 24.4$ & - \\
\hline $\begin{array}{l}\text { O'Leary-sant interstitial cystitis } \\
\text { symptoms index }\end{array}$ & $\begin{array}{l}14.7 \pm 2.2 \\
(10-20)\end{array}$ & - \\
\hline Frequent urination, n/\% & $24 / 58.5$ & - \\
\hline Imperative urination, $\mathrm{n} / \%$ & $11 / 26.8$ & - \\
\hline Urgent incontinence, $\mathrm{n} / \%$ & $6 / 14.6$ & - \\
\hline Bladder capacity, M $\pi$ & $\begin{array}{l}276.0 \pm 61.8^{*} \\
{[108 ; 360]}\end{array}$ & $\begin{array}{l}405.4 \pm 37.2 \\
{[322,486]}\end{array}$ \\
\hline Urethral polyps, n/\% & $5 / 12.2$ & \\
\hline \multicolumn{3}{|l|}{ Cystoscopy of the bladder mucosa } \\
\hline Without changes, n/\% & $4 / 9.7^{*}$ & \multirow[t]{5}{*}{$20 / 100$} \\
\hline Diffuse submucosal hemorrhages, n/\% & $18 / 43.9$ & \\
\hline Glomerulations, n/\% & $8 / 19.5$ & \\
\hline Diffuse bleeding, n/\% & $6 / 14.6$ & \\
\hline Hunner lesions, n/\% & $5 / 12.2$ & \\
\hline
\end{tabular}

the control group, the NGF level ranged from 0 to $746.19 \mathrm{ng} /$ $\mathrm{mL}$, which averaged $130.69 \pm 124.985 \mathrm{ng} / \mathrm{mL}$. The measurement of the concentration of IL-8 in urine showed its increase in the patients in the main group. The average level in the main group was $51.3 \pm 9.36 \mathrm{pg} / \mathrm{mL}(30.4-67.6 \mathrm{pg} / \mathrm{mL})$ and in the control group was $24.1 \pm 5.37 \mathrm{pg} / \mathrm{mL}(11.2-31.0 \mathrm{pg} / \mathrm{mL})$. When evaluating the biopsy samples, inflammatory cell infiltration was revealed (Table 2).

Mast cells correlated with weak feedback with plasma cells ( $r=-$ $0.228)$, neutrophils $(r=-0.227)$, and lymphocytes $(r=-0.156)$.

While the correlation analysis did not reveal any relationship between NGF and IL-8, there was a weak relationship between the level of NGF and IL-8 with the cells of the bladder biopsy (Table 3).

Table 2. Cellular spectrum of bladder biopsies in women with interstitial cystitis/bladder pain syndrome

\begin{tabular}{|l|l|}
\hline Indicators & Main group $(\mathbf{n}=41)$ \\
\hline Mast cells & $82.27 \pm 38.76(0-237)$ \\
\hline Eosinophils & $1.61 \pm 1.44(0-22)$ \\
\hline Lymphocytes & $238.0 \pm 166.42(12-589)$ \\
\hline Neutrophils & $26.06 \pm 17.67(0-312)$ \\
\hline Plasma cells & $60.12 \pm 53.26(0-221)$ \\
\hline
\end{tabular}

Table 3. Correlation coefficient of cells with nerve growth factor and IL-8

\begin{tabular}{|l|l|l|}
\hline Cells & NGF & IL-8 \\
\hline Mast cells & +0.120 & +0.062 \\
\hline Eosinophils & +0.053 & +0.165 \\
\hline Lymphocytes & +0.017 & -0.117 \\
\hline Neutrophils & -0.129 & $-0,158$ \\
\hline Plasma cells & +0.187 & -0.131 \\
\hline NGF: Nerve growth factor & & \\
\hline
\end{tabular}

\section{Discussion}

In this study, we reviewed the anamnesis, clinical picture of patients with IC/BPS. The predominant symptom of IC/BPS is pain (16). In women with IC/BPS, severe pain was observed in $24.4 \%$, moderate in $56.1 \%$, and mild pain in $19.5 \%$ of cases. Bladder volume ranged from $108 \mathrm{~mL}$ to $360 \mathrm{~mL}$. A capacity of $<200 \mathrm{~mL}$ was reported in $7.3 \%$ of patients, which is consistent with other researchers who note that only about $8 \%$ of the patients have a small volume of bladder (200 mL) (17).

IC/BPS diagnosis often includes the exclusion of disorders such as malignancy, infectious processes, bladder hyperactivity, and other sources of bladder pain and urinary symptoms that can mimic IC/BPS symptoms. There is no consistent cystoscopic 
diagnostic results for IC/BPS because cystoscopy can be completely normal in many patients (18). According to our data, 9.7\% of patients had no changes in cystoscopy. However, Hunner's lesions and inflammatory phenomena are often the only cystoscopic findings that contribute to the diagnosis of IC/BPS (19). In addition, petechial hemorrhages, also known as glomerulations, were identified as diagnostic signs, but they can also be found in asymptomatic patients. In our investigation, out of the 41 patients in the main group, only $8(19.5 \%)$ had glomerations that covered $>60 \%$ of the bladder surface.

Our results showed a slight increase (8.13\%) of NGF in urine in patients with IC/BPS compared to the control value and a statistically significant increase in IL-8-53.0 $(p<0.05)$. Our data on elevated NGF in urine at IC/BPS are comparable to the results of Tonyali et al. (8) and Kim et al. (20). However, in our studies, the difference was not statically significant, whereas according to these authors, the increase was statistically significant. Currently, many researchers propose to introduce urinary NGF as a biomarker (21). It regulates the development and maintenance of sensory and sympathetic neurons and plays a role in painful somatic and visceral inflammation (22).

It is believed that the urinary NGF plays a key role in the correlation between inflammation and pain impulse, as it is produced by urothelial cells, smooth, and mast cells activating their degranulation and proliferation (22).

Chronic inflammation leads to increased secretion of NGF in the urine which leads to morphological changes in the system of sensitive and motoneurons of the bladder. Nevertheless, despite the availability of numerous studies aimed at the search for new IC/BPS biomarkers, the contribution of NGF to the bladder function is not entirely clear.

Although the results showed an increase in the NGF and IL-8 levels, they did not correlate with each other. However, in the etiology of IC/BPS, these indicators as factors of inflammation play an important role, as inflammation has a direct effect on the function of the bladder (23). Chronic inflammation of the bladder is accompanied by infiltration of the bladder wall by lymphocytes, mast, and plasma cells leading to irreversible changes in tissues. Moreover, the analysis of the obtained data showed that the morphological picture was represented by different degrees of expression by cellular infiltration, mainly lymphoplasmatic with mast cells. Our study found the correlation of mast cells with neutrophils and plasma cells. In addition, the cystoscopic picture (the presence of glomerulation, Hunner's lesions, the severity of hematuria, and bladder volume) did not directly correlate with the morphological changes in the biopsy specimens. Approximately similar data were obtained by Syed et al. (24).
Modern electron microscopy and modern immunohistochemistry data as well as staining methods confirm the central role of mast cells in the pathogenesis and pathophysiology of IC/BPS. However, researchers recommend continuing research aimed at finding IC/BPS biomarkers.

\section{Study Limitations}

The main limitation of the present study is the small group of surveyed patients. However, identifying urinary biomarkers with IC/BPS will improve the diagnostic strategies and reduce patient invasiveness, while also improving the exclusion criteria and reducing the diagnostic time.

\section{Conclusion}

In patients with IC/BPS, an increase of urinary NGF and IL-8 levels was observed. Inflammatory cell infiltration of biopsy samples of the bladder mainly by lymphocytes and mast cells was detected. A weak correlation was found between the NGF and mast cells, neutrophils, and plasma cells. IL-8 was correlated with a weak direct relationship with eosinophils and reverse with neutrophils and plasma cells. The obtained results contribute to a better understanding of the etiology of IC/BPS and can be included in the complex of diagnostic studies.

\section{Ethics}

Ethics Committee Approval: This study was approved by the Ethics Committee of the Republican Centre of Diagnosis and Treatment (number: 2018/136).

Informed Consent: Informed consent was obtained for each patient and the examined control group.

Peer-review: Externally peer-reviewed.

Financial Disclosure: No financial support was received for this study.

\section{References}

1. Wang J, Chen Y, Chen J, Zhang G, Wu P. Sacral Neuromodulation for Refractory Bladder Pain Syndrome/Interstitial Cystitis: a Global Systematic Review and Meta-analysis. Sci Rep 2017;7:11031.

2. American Urological Association (AUA) Guideline Diagnosis and treatment of interstitial cystitis/bladder pain syndrome. 2011:57.

3. Hanno PM, Erickson D, Moldwin R, Faraday MM. American Urological Association. Diagnosis and treatment of interstitial cystitis/bladder pain syndrome: AUA Guideline Amendment. J Urol 2015;193:1545-1553.

4. van de Merwe JP, Nordling J, Bouchelouche P, Bouchelouche $K$, Cervigni M, Daha LK, Elneil S, Fall M, Hohlbrugger G, Irwin P, Mortensen S, van Ophoven A, Osborne JL, Peeker R, Richter B, Riedl C, Sairanen J, Tinzl M, Wyndaele JJ. Diagnostic criteria, classification, and nomenclature for painful bladder syndrome/interstitial cystitis: an ESSIC proposal. Eur Urol 2008;53;60-67.

5. Patnaik SS, Laganà AS, Vitale SG, Butticè $S$, Noventa M, Gizzo S, Valenti G, Rapisarda AMC, La Rosa VL, Magno C, Triolo 0, Dandolu V. Etiology, 
pathophysiology and biomarkers of interstitial cystitis/painful bladder syndrome. Arch Gynecol Obstet 2017;295:1341-1359.

6. Bouchelouche K, Bouchelouche P. Mast Cell and Bladder Pain Syndrome. In: Nordling J., Wyndaele J., van de Merwe J., Bouchelouche P., Cervigni M., Fall M. (eds) Bladder Pain Syndrome. Springer, Boston, MA 2013:71-86.

7. Evans RJ, Sant GR Current Diagnosis Of Interstitial Cystitis: an Evolving Paradigm. Urology 2007;69:64-72.

8. Tonyali $S$, Ates $D$, Akbiyik $F$, Kankaya D, Baydar D, Ergen A. Urine nerve growth factor (NGF) level, bladder nerve staining and symptom/problem scores in patients with interstitial cystitis. Advances in Clinical and Experimental Medicine 2018;27:159-163.

9. Qu HC, Zhang W, Yan S, Liu YL, Wang P. Urinary Nerve Growth Factor Could Be a Biomarker for Interstitial Cystitis/Painful Bladder Syndrome: A MetaAnalysis. PLoS One 2014;9:e106321

10. Liu HT, Kuo HC. Biomarkers for patients with interstitial cystitis/bladder pain syndrome. Urological Science 2015;26:225-229.

11. Regauer $\mathrm{S}$. Mast cell activation syndrome in pain syndromes bladder pain syndrome/interstitial cystitis and vulvodynia. Transl Androl Urol 2016;5:396397.

12. Gonzalez EJ, Arms L, Vizzard MA. The Role(s) of Cytokines/Chemokines in Urinary Bladder Inflammation and Dysfunction. BioMed Research International 2014. Article ID 120525, 17p.

13. World Medical Association Declaration of Helsinki Ethical Principles for Medical Research Involving Human Subjects. JAMA 2013;310:2191-2194.

14. O'Leary MP, Sant GR, Fowler Jr FJ, Withmore KE, Spolarich-Kroll J. The interstitial cystitis symptom index and problem index. Urology 1997;49(Suppl 1):58-63.
15. Bayrak O, Seckiner I, Solakhan M, Karakok M, Erturhan SM, Yagci F. Effects of Intravesical Dexpanthenol Use on Lipid Peroxidation and Bladder Histology in a Chemical Cystitis Animal Model. Urology 2012;79:1023-1026.

16. Fuentes IM, Christianson JA. The influence of early life experience on visceral pain Front. Syst Neurosci 2018;12:2.

17. Mishra NN. Clinical presentation and treatment of bladder pain syndrome/ interstitial cystitis (BPS/IC) in India. Transl Androl Urol 2015;4:512-523.

18. Jhang JF, Kuo HC. Pathomechanism of Interstitial Cystitis/Bladder Pain Syndrome and Mapping the Heterogeneity of Disease Int Neurourol J 2016;20(Suppl 2):95-104.

19. Hunner GL. A Rare Type of Bladder Ulcer: Further Notes and a Report of 18 Cases. JAMA 1918;70:208-212.

20. Kim SW, Im YJ, Choi HC, Kang HJ, Kim JY, Kim JH. Urinary Nerve Growth Factor Correlates with The Severity of Urgency and Pain. Int Urogynecol J 2014;25:1561-1567.

21. Liu HT. Biomarkers for Patients with Interstitial Cystitis/Bladder Pain Syndrome. Urological Science 2015;26:225-229.

22. Kim J, Kim WT, Kim WJ. Advances in urinary biomarker discovery in urological research. Investig Clin Urol 2020;61:8-22.

23. Jiang $\mathrm{YH}$, Jhang JF, Hsu YH, Ho HC, Wu YH, Kuo HC. Urine Cytokines as Biomarkers for Diagnosing Interstitial Cystitis/Bladder Pain Syndrome and Mapping Its Clinical Characteristics. Am J Physiol Renal Physiol 2020. https://doi.org/10.1152/ajprenal.00051.2020.

24. Syed $\sqcup$, Illchak DL. Bladder Pain Syndrome in Females. The Journal for Nurse Practitioners 2017;13:291-295. 